\title{
Back to the Ivory Tower? The Professionalisation of Development Studies and their Extension to Europe
}

\section{Dudley Seers}

The convention is that development studies cover only the 'developing' countries of Africa, Asia and Latin America, a sort of academic counterpart of OXFAM. But this convention is ceasing to be viable for European social scientists, and indeed it is starting to be harmful. The assumption that 'their' problems are intrinsically different from 'ours' is not merely patronising; it has become a hindrance to the transfer of experience. It is also associated with political commitment of a sort that hinders professional progress.

The extension of development studies to Europe

The artificiality of the distinction between 'developed' and 'developing' is perhaps most obvious in Europe. Portugal, for example, has been a member of OECD's Development Assistance Committee, as well as the group of 'developed market economies' at UNCTAD. Yet anyone familiar with 'developing' countries, especially in Latin America, finds the Portuguese scene instantly recognisable (Bienefeld and Seers, 1976). A similar structural dualism, with much lower incomes, worse social conditions and higher fertility in the (relatively large) population of the rural areas. A similar concentration in the ownership of property, especially land. A similar pattern of trade, with tourist services, primary products and textiles exchanged for arms, equipment, intermediate products and sophisticated consumer goods. A similar prevalence of transnational corporations (TNCs) in secondary industry and the services (especially big hotels). Similar inappropriate technologies and associated chronic unemployment, relieved (as in many 'developing' countries especially in Central America and the Caribbean) by large-scale migration abroad. A not very different cultural dependence on foreign styles of consumption and on imported ideologies, fed by foreign firms, television programmes, etc. The same sort of bureaucracy with a striking combination of complacency and inefficiency. Similar organised terrorism of both Right and Left and similar political manipulation by dominant powers.

Two basic politico-economic patterns characterise 'developing' countries. In one, a military dictatorship maintains a strong and stable currency by creating a favourable climate for foreign capital, which implies suppressing trade union activity and political opposition; in the other, a 'soft' government is unable to resolve internal class conflicts, the symptoms of its failure being chronic inflation and foreign exchange difficulties, relieved only by periodic devaluation. ${ }^{1}$ Portugal has demonstrated both patterns recently-the former before the 1974 coup, the latter after it. Such a sudden and complete political somersault is also itself characteristic.

Roughly similar socio-economic features and patterns, including heavy dependence on labour migration and tourism, can be seen in many countries of Southern Europe-Spain, Malta, Yugoslavia, Greece, Cyprus and Turkey-and also in the Irish Republic and Finland. So 'Third World' experience-for example in dealing with the TNCs - is likely to be relevant to their problems too. Their social sciences would also gain from an injection of the work of Latin American theorists-as has indeed started to occur (Guzman, 1976); this is likely to be more appropriate to such countries than neo-classical economics, or other theories imported from culturally dominant countries. ${ }^{2}$

But if 'development studies' are to cover these countries, why not Italy too? It shows many of the same characteristics, notably a big economic and social gap between the cities of the North and the rural areas of the South (including Sicily and Sardinia). It displays economic, cultural and political dependence (including reliance on foreign tourism and labour migration), though less than in Portugal. Successive Italian governments have also faced typical 'Latin American' problems of chronic foreign exchange deficits and inflation, especially since the 1973 rise in the price of oil.

And if Italy, why not Britain, the other economically 'weak' member of the EEC? It is true that Britain is -in contrast to most 'developing'

1 There are of course hybrids, especially where (as in Argentina and Chile) the structural causes of inflation are too deepseated to be eradicated by even ruthless military regimes.

2 IDS, in collaboration with CLACSO, is about to issue a select bibliography of key Latin American writings on deveolpment (with references to English and French trans lations where available). 
countries-highly industrialised and urbanised. Although Scotland, Wales and Northern Ireland are in some senses less developed than South-East and Central England, regional economic inequalities are mitigated by a powerful fiscal machine. Poverty, even in the Highlands of Scotland, is not comparable with what can be found in Latin America or Portugal. Moreover, much of industry is still British-owned. The country continues to be a generator as well as an importer of capital, technology, arms, equipment and cultural artefacts (such as television programmes). It continues to absorb immigrant manpower of various types (especially from the Irish Republic), even if the net inflow is now negligible; and many British tourists continue to visit the Continent, although there is now a strong flow in the opposite direction. Britain is, moreover, a country which has been falling behind rather than failing to catch up.

But the question is not the trivial quasi-joke about whether Britain is a 'developing' country. It is whether the insights gained in development studies would be helpful to those working on British problems, in view of its dependence on foreign-based TNCs, and the difficulty its government finds in reducing the pace of inflation, the foreign exchange deficit and the level of unemployment (despite exceptional trade union cooperation and mounting revenues from North Sea gas and oil) (M Phil faculty and students, 1977).

Typical symptoms of dependence are the tendency to await an acceleration of economic growth in the United States as the solution to national economic problems, a reliance on TNCs for new investment bringing modern technology-as in the North Sea oilfields-and the publicity given to arrivals of IMF missions. (It is rather curious, even dispiriting, to hear in Britain now the same old arguments for and against 'monetarist' policies which have dominated Latin American economic controversy for the last quarter-century. British politicians are apparently, like British economists, too parochial even to be aware of them.)

Development studies have made us familiar with the core-periphery concept: Western Europe seems to have its own core and periphery. What is more, there is a definite geographical pattern to it, with the European periphery ${ }^{3}$ forming a ring around the core, whether defined in terms of countries or of regions cutting across national boundaries

3 This concept will be explored more fully in later work. (including in the core, for example, Northern Italy and most of England).

This raises a number of intriguing questions. How is this European pattern related to the dependence of the whole of Western Europe on the United States? To what extent can we see a similar pattern in Eastern Europe? If so, is the core East Germany? In that case, can we speak of a continental dependence system (a 'new order'?) in Europe based on Germany, West and East? Does this suggest an eventual integration of Eastern and Western Europe? Or is the whole of Eastern Europe too heavily dependent on the Soviet Union?

Insights acquired from work in the development field would throw light on several European policy issues, including those raised by the enlargement of the EEC. For example, anyone who has worked on industrial or agricultural policy overseas will know that a simplistic cost-benefit analysis based on internal rates of return for individual projects such as EEC financial agencies use (Bienefeld and Seers, 1976), will be far from suitable for evaluating sectoral or local programmes with objectives that include reducing unemployment and inequality. (Aid agencies such as ODM might well turn their attention and at least a small part of their resources to such problems: they should certainly be involved in negotiations on enlargement.)

This extension of development studies also has interesting implications for 'North-South' negotiations. If certain countries of Europe, including Britain, and the Third World share problems with common causes, then is there not a basis for much greater cooperation in international fora, such as UNCTAD, on many issues for example monitoring the TNCs? And might not European governments benefit from technical assistance from agencies with international experience in problems like structural unemployment (e.g. the ILO)?

This geographical extension of development studies would not merely contribute to a deeper understanding of European problems, but also conversely throw light on the problems of the countries conventionally covered by development studies. The ring-like periphery of Europe prompts us to reflect on the wider significance of spatial analysis, and to look for similar patterns in other areas: the Northern half of the Western Hemisphere, Southern Africa and the South Pacific spring to mind. This would be a refinement on the somewhat global core-periphery analysis current in development studies. 


\section{Political expedience and development studies}

What stops the inclusion of the European periphery in development studies? It is the convention under which the field deals with aided countries. The origins of its current definitions lie in political expendiency allied to commercialism, humanitarianism and academic territorialism-a powerful and somewhat unholy alliance.

As the Cold War intensified in the 1950s and former colonies became independent, political attention in the metropolitan countries focused on problems of 'underdevelopment', which were seen as potential breeding grounds for communism. When three groupings emerged in the politics of international organisations - the 'developed' countries with high per capita incomes, the 'centrally planned', and the large residual category of the 'developing' - the last was treated as qualitatively different and alone in need of support from aid agencies and development economists.

This tripartite division of the world was of course both novel and highly artificial. But, as I have pointed out earlier (Seers, 1976), it did have some basis in reality. It recognised the common problems and interests of the governments of developing' countries vis $\grave{a}$ vis the companies and governments of richer countries) and their common historic resentments. The governments in the 'developed' countries were prepared to institute aid programmes designed, inter alia, to keep those outside the communist bloc still 'developing'. Yet it allowed the bureaucratic class in the communist countries to consider governments of various political complexions as anti-imperialist, and to lend them diplomatic support while leaving to the imperial powers themselves the responsibility for financial and technical aid.

Soon the three world classification acquired a life of its own. Typically, the governing councils of international agencies have balanced representation between 'centrally-planned', 'developed' and 'developing' countries, and so have their committees, expert groups, missions, etc. Many governments of 'developing' countries have come to consider 'Third World unity' a major source of strength. All sorts of institutions have grown up to facilitate 'South-South' and 'North-South' discussions and negotiations.

Academic work in 'developed' countries on the problems of the 'developing' countries was also influenced; though it had started much earlier, especially in the fields of anthropolgy and colonial economies. When aid departments and the United Nations agencies and regional commissions were established, in response to the various political interests mentioned above, much greater opportunities were provided for both field and desk research on 'developing' countries. Special development institutions such as IDS were also set up.

Those engaged in research in this field have accepted the geographical definition used by its sponsors. ${ }^{4}$ Moreover, one is bound to say that some of it has not been as objective as is perhaps customary in the social sciences. There has been an implicit assumption that the ultimate goals would be European-style political institutions and levels of living within a capitalist system-basically the same goals as those of colonial governments. Many researchers in colonial times and subsequently have also assumed (usually tacitly) that those with political power were sufficiently motivated and efficient to achieve these ends, and that they could and would make good use of technical and financial assistance. This has amounted to a new (though very different) 'trahaison des clercs'. Elaborate models were worked out to help policymakers accelerate economic growth and (when political concerns changed) to deal with problems such as high-level manpower shortages, unemployment, inequality and poverty. Development research in all these areas has been marked by conceptual imprecision and a very casual use of statistics-as was inevitable if 'results' were to be provided for policy-makers, but primary data were meagre or non-existent.

Several development courses were established in Europe. These were more or less explicitly designed to 'train' people how to run their own countries (often being succesors to colonial service courses), though they sometimes also had places for those from 'developed' countries who were primarily interested in the problems of the "Third World'.

Many European academics have also been heavily involved in advisory work on 'development'. These have often done little or no similar work on the problems of their own countries. The very understandable desire to do something about the

\footnotetext{
4 The idea of treating European countries as cases for development is not, however, really at all novel, Development studies were born in Europe. I am not referring to the work of Adam Smith or Karl Marx or even the industrialisation debate in the Soviet Union in the 1920s: the first two development studies in the modern sense were written by Rosenstein-Rodan (1943) and Martin, né Mandelbaum (1947). They dealt with the post-war development needs of Eastern and South-Eastern Europe. These were followed by work on the Italian South by Rosenstein-Rodan, Chenery and others. This work on Europe was, however, submerged in the swelling torrent of research on Africa, Asia and Latin America.
} 
poverty of the rural masses in the tropics has been reinforced by rather flattering invitations to propose solutions to their problems.

Inevitably, much of this work has been superficial. We economists in particular have often offered advice without much knowledge of the history or the political context of the country concerned and therefore with little basis for framing the questions to be studied, let alone predicting the results of our advice. In fact, we have rarely known or even enquired what political interests our visits have served (and of ten the real motive of an invitation has been to obtain our signatures rather than our opinions). The actual outcome of such well-meaning intervention has sometimes been inadvertently to strengthen regimes obstructing the very changes we have advocated-which may of course sometimes have been the intention all along of the donor agencies sponsoring our travels. Indeed, there is now a fairly widespread disillusion about the effectiveness of high-level technical assistance in the face of powerful hostility to social change or indifference.

Events in recent years, especially the 'oil crisis' and the subsequent recession, have made the three-world classification much less realistic. As explained above, some European countries have developed 'Latin American' symptoms: indeed, few of them are acceptable any longer as models to the rest of the world nor do their governments have the resources-given their domestic problems - to sustain big aid programmes or paternalistic roles. Communist countries have also developed unevenly and no longer form such a homogeneous group with respect to either institutions or policy. The growing detente between their governments and those of capitalist countries raises basic questions about the rationale of a world classification that originated in the Cold War. Enormous differences in politico-economic power have also appeared within the Third World. The per capita incomes of most oil exporters and of some other countries-to take the common yardstick on the conventional approach-now exceed those of some European countries (indeed Kuwait has the highest per capita income in the world), and what is more to the point, their governments have essential products to sell and capital to invest.

One can perhaps see parallels with the blurring of class divisions inside European countries, where sections of the working class have achieved a bargaining strength and income levels higher than many of those conventionally considered 'middle class' (and labour studies have been extended beyond their traditional field, the manual workers).

The oil crisis not merely undermined the old three-world classification, and demonstrated that there were other ways of obtaining capital than waiting for aid, it threw doubt on the basically optimistic assumptions that underlay much of the research and advice in this field. Limits to oil and other non-renewable resources have raised serious doubts whether all the countries of the world will become 'developed' even in the remote future, and their populations as a whole able to afford cars and other elements in the level of living of the European working class. While we are not entering a 'zero sum' game, the sum no longer seems infinite.

International relations are characterised by a new ruthlessness, and the position of many 'developed' countries, especially those dependent on imported oil, has become precarious. As happened inside the industrial countries themselves, the representatives of the poor are not waiting any more for charitable concessions, but starting to organise to extract what they can.

\section{The quandary of the European academic}

What is the European social scientist to do? Certainly some will continue to carry out research, training and consultancy exclusively on behalf of 'developing' countries and much of this has no doubt a certain value. Often the underlying assumption is that it is desirable to redistribute income towards these countries, however, the idea of a European devoting his energies to shifting resources to foreign governments now seems rather anomalous, especially if they go to support and strengthen the bureaucracy. Yet advocacy of redistribution inside other countries raises uncomfortable questions about paternalism and the propriety of urging sacrifices on other bourgeois, quite apart from the very doubtful effectiveness of such advice. Analogous questions are raised even more sharply for those whose work implies the need for others to carry out revolutions.

This complex of intellectual and moral uncertainties recalls the doubts that troubled the European intelligentsia in the Reformation. The reality is that there is very little we can do as either officials or academics to improve social conditions in other continents-although we can perhaps make them worse! It is not surprising that some European social scientists who had specialised in development have been leaving the field. For those who remain, the first step in changing our 
role is to acknowledge the obvious social and political problems in our own country; the second is to accept the validity and utility of nationalism as a shield against dependence; and the third to realise that transfers of resources to countries which are poorer may well, given the extent of our own problems and the difficulties of reaching those in real need, not increase net welfare.

For some, the next step after this is to search for interface policies that will reconcile the needs of those in developed and developing countries. Others see their task as exploring-in alliance with the ecologists-what changes in lifestyles in developed countries would relieve the pressure on oil and other scarce resources, thus creating greater economic space for satisfying basic needs in poorer countries. I will not go into detail here on the pros and cons of these new approaches. They are certainly much healthier than the old concern with the policies of foreign governments. But they raise big questions of political feasibility and do not entirely avoid the invidious task of defining other people's needs.

Perhaps some European social scientists need to draw more far-reaching conclusions. The kernel of development studies will surely become the concentration of economic and political power, and the consequent creation of poverty, both absolute and relative, wherever this occurs, not just in the so-called Third World, but also in Europe. This process of marginalisation is not purely economic: it includes threats to national, regional or ethnic identity. Its study involves analysis of the institutions, especially international which in various ways transmit the techniques, tastes, theories and ideologies that generate inequality-including inequalities between and within European countries.

Explaining its causal dynamics leads into deeper historical, as well as broader geographical, analysis than has been customary in our field so far. It means investigating the origins of the present world structure, especially the creation and disolution of the colonial system, which was of course based in Europe, and drawing on all parts of the world for case studies in teaching as well as research.

The professionalisation of development studies will be helped by their extension to European countries and vice versa. Besides providing fresh insights into ilational and regional problems in Europe, the application of development analysis there will make obsolete, at least in academic work, the professionally dubious distinction between 'developed' and 'developing' countries, the models and the emulators. ${ }^{5}$ Conversely, it is difficult to extend development studies to Europe until we have discarded a classification of countries which originated primarily in political expediency.

That there are strongly entrenched vested interests against this change of emphasis is implicit in the foregoing analysis. To abandon the 'Third World' as a category, and give up using the phrase itself, would dilute the political cement holding together a coalition which has become even more useful to the governments of the countries concerned. 'North-South' negotiations would lose their rationale: 6 indeed both 'North' and 'South' would disappear as concepts (though of course the basic issues of commodity and energy policy and so forth would still need to be discussed).

The new approach threatens the political constituency of the bilateral aid administrator, based on transnational corporations and voluntary agencies, and seems heartless to those whose main concern is humanitarian. Some on the West European Left would find it hard to accept the validity of their own country's interests. Officials in Communist countries would be very suspicious of their own internal problems being put in this framework. Any European government (West or East) would find it hard to cooperate politically with governments of 'developing' countries or to apply for technical assistance, in part because of the residues of paternalism. Fundamental changes would be needed in the structures and procedures of international agencies and national administrations.

A heavy cost would also be borne by academics themselves: research covering exclusively 'developing' (or, for that matter, exclusively 'developed') countries would quickly become obsolete, lecture

\footnotetext{
5 I am sometimes asked how I reconcile my present position with my criticisms in the early 1960 s of the naive transfer of economic theories developed in Europe and North America to countries in other continents with quite different institutions-e.g. in my "The Limitations of the Special Case' (originally published in Bulletin, Oxford Institute of Economics and Statistics, 1962). In the first place, that battle has partly been won: social science syllabuses of universities in other continents are no longer modelled so closely on those of Eurpe and North America. But, in addition, the changes outlined above in the international scene have created conditions in which it is more constructive now to emphasise the common elements of problems. Besides, I was then arguing against transferring theories devised for the 'developed' countries to the Third World. I am now advocating a transfer in the reverse direction: it seems that the theories devised for the "developed' countries (such as Keynesian and other forms of neo-classical economics) are ceasing to be appropriate even in the countries where they originated.

6 The North-South 'dialogue' reflects the seating arrangements in the British House of Commons, where the parties confront each other: one might view the world political structure as more like the continuous arc of the French Chamber.
} 
notes in the field of development studies might have to be torn up, reading lists substantially revised and inventories of textbooks written off. Libraries would need to be reorganised and their purchasing policies broadened. Training courses (if 'training' is the right word in this field) would have to include European material, and to aim at the enrolment of students from Europe who are working on European problems and of teachers from other continents. Offers of consultancies would be treated much more warily. Development studies as redefined above would no doubt remain a separate field characterised by interdisciplinarity, an historical approach, an emphasis on international determinants and a focus on institutional issues. It would still be marked by greater concern for social problems, particularly poverty, than is customary among academic social scientists, and greater need for the first-hand acquaintance with these problems that can only be provided by fieldwork (though of a less paternalistic kind). But the boundaries dividing it from the conventional social sciences would be hazier and easier to violate. Those in development institutes would have to familiarise themselves with work on their own country and also face the 'rigorous' standards of their colleagues in disciplinary departments. The latter on the other hand would hardly feel comfortable in closer contact with the messy and largely unquantifiable problems of the real world.

It will therefore take quite some time for development studies to escape from their traditional boundaries. From the viewpoint of the European academic, however, there would be major benefits to offset against the short-term costs of its redefinition. Awkward moral tensions would be eased. Challenging possibilities would be opened up for more objective and fundamental research, based (to the extent that quantitative analysis is possible) on proper statistics. We would be less at the mercy of changes in political winds. Our own social science syllabuses could be made more relevant to our own continental, national and regional problems. In addition, European social scientists could become genuine colleagues of those in other continents-something hardly possible so long as development studies exclude Europe.

We are brought back therefore to the oldfashioned conclusion that academics had best use long spoons when supping with politicians. Their immunity from political pressures has been defended on the ground that it was necessary for innovative professional work. In development studies, this defence has been imparied. I am not, however, suggesting that the subject's social relevance should be reduced; rather that those inside government or outside should be left to draw whatever conclusions are relevant to their own occupation, nationality and ideology. The study of the constraints on national policy is potentially significant for people of many types, inside or outside government. Politicians and officials may well take more notice of the contributions of academics who are less partisan, and therefore more readily reconsider the assumptions on which their aproaches are based.

But that would be so-to-speak a by-product. A more important result of some degree of detachment of development studies from the aid lobby is that this would facilitate the coverage of European problems. While it can be argued plausibly (if perhaps mistakenly) that development theory and experience, as conventionally defined, can contribute little to the analysis of the problems of countries such as the United States and the Soviet Union, this is obviously untrue of Portugal and other countries in the European periphery. They provide the bridge for the extension and thus professionalisation of development studies.

\section{References}

Bienefeld, Manfred, and Seers, Dudley, 1976, 'Industrial Planning and the Use of External Assistance in Portugal', OECD (Mimeo)

Guzman, Gabriel, 1976, 'El desarrollo latinoamericano y la CEPAL', Editorial Planeta, Barcelona

Mandelbaum, Kurt, 1947, 'The Industrialisation of Backward Areas', OUP, Oxford

M Phil faculty and students, 1977, North Sea Oil: The Application of Development Theories, IDS Communication 121

Rosenstein-Rodan, Paul, 1943, 'Problems of the Industrialisation of Eastern and South-Eastern Europe', Economic Journal, June-September

Seers, Dudley, 1976, 'A New Look at the ThreeWorld Classification', IDS Bulletin, Vol. 7, No. 4 